\title{
ІННОВАЦІї ЯК СКЛАДОВА ФАКТОРІВ ВПЛИВУ НА СТАБІЛЬНИЙ РОЗВИТОК СУЧАСНОГО ПІДПРИЕМСТВА
}

\section{DOI: 10.32620/cher.2019.1.05}

\begin{abstract}
Постановка проблеми. Орієнтація на інноваційний розвиток і економічне зростання, що ним забезпечується, дозволяють сьогодні домогтися підприємствам конкурентних переваг не тільки у виробництві і реалізації продукції (робіт, послуг), а й перш за все в способах організації бізнесу. Теорія інноваційного розвитку в економіці, яка $є$ однією з головних економічних доктрин сучасності для великого числа країн світу, в Україні зараз тільки формується і знаходиться в стадії активного розвитку. Розгляд особливостей та проблем інноваційних процесів вітчизняних підприємств обумовлений необхідністю підвищення їх конкурентоспроможності на внутрішніх і зовнішніх ринках. Mета сmammi полягає у розвитку теоретико-методичних засад у сфері розвитку підприємства на основі інновацій, визначенні ролі інновацій для забезпечення стабільного розвитку підприємства. Об'єктом дослідження виступає формування інноваційної стратегії підприємства та їі компонентів для реалізації інноваційного проекту. Методи, використані в дослідженні: системний підхід, метод узагальнення, порівняння. Основною гіпотезою є те, що інновації відіграють важливу роль у забезпеченні стабільного розвитку підприємства. Виклад основного матеріалу. Визначено, що інноваційний розвиток є наслідком інноваційних процесів, що відбуваються на підприємстві. У своєму інноваційному розвитку підприємства проходять ряд стадій: наукові дослідження, освоєння і впровадження. Основними властивостями інновації є наукова новизна, практична застосовність, комерційна реалізованість. Розглянуто методику формування стратегії для впровадження інновації та іiі види для підвищення конкурентоспроможності підприємства, стадії та складові інноваційного процесу. А також фактори, які можуть вплинути на формування і результат інвестиційно-інноваційного проекту. Оригінальність та практичне значення дослідження. Стаття дає уявлення про роль інновацій для сучасного підприємства і допомагає визначити основні орієнтири розвитку і впровадження інноваційних рішень. Автором відображені найважливіші властивості економічних інноваційних процесів, які істотно відрізняють їх від інших бізнес-процесів. Висновки дослідження. Зроблені висновки, що в умовах сучасного економічного середовища інновації для підприємства - необхідна умова виживання. Проте впроваджуючи інновації керівники всіх ланок стикаються 3 проблемою невизначеності нових факторів, які мають суттєвий вплив на «роботу» інноваційного процесу та на діяльність підприємства в цілому. Результати дослідження можуть бути використані при розробці стратегії реалізації інноваційного процесу на підприємстві будь-якої форми організації.

Ключові слова:

Стабільний розвиток, інновації, стратегія підприємства, інноваційний процес.
\end{abstract}

\section{INNOVATIONS AS AN INTEGRAL PART OF THE FACTORS INFLUENCING THE SUSTAINABLE DEVELOPMENT OF A MODERN ENTERPRISE}

Formulation of the problem. Orientating to the innovative development and economic growth, provided by them, nowadays allows enterprises to achieve competitive advantages not only in the production and sale of products (projects, services), but above all in the methods of business development. The theory of innovative development in the economy, which is one of the main economic doctrines of modern times for a large number of countries in the world, is now only being formed in Ukraine and is in the stage of active development. Considering the features and problems of the innovation processes of domestic enterprises, there is a need to further develop their competitiveness for domestic and external markets. The purpose of the article is to develop the theoretical and methodological foundations in the field of enterprise development based on innovation, as well as to determine the role of innovation to ensure the stable development

1 Лучишина Єлізавета Вікторівна, аспірант кафедри «Фінанси», Національний аерокосмічний університет ім. М. С. Жуковського «Харківський авіаційний інститут», м. Харків, Україна.

Lutsyshyna Yelyzaveta, post-graduate student of Finance Department National Aerospace University «Kharkiv Aviation Institute», Kharkiv, Ukraine.

ORCID ID: 0000-0002-9594-0948

e-mail: lutsysh@gmail.com 
of the enterprise. The object of the study is the formation of an innovative strategy of the enterprise and its components for the implementation of an innovative project. Methods used in the research are a systematic approach, a method of generalization, comparison. The hypothesis of research is that innovation plays an important role in ensuring the stable development of the enterprise. The statement of basic materials. It is determined that innovative development is a consequence of innovative processes occurring in the enterprise. In its innovative development, enterprises go through a number of stages: research, development and implementation. The main properties of innovation are scientific novelty, practical applicability and commercial feasibility. The method of forming a strategy for the introduction of innovation, types of improvement of the competitiveness of the enterprise, stages and components of the innovation process are all considered, as well as factors that may affect the formation and outcome of the investment and innovation project. Originality and practical significance of the research. The article gives an idea of the role of innovation for a modern enterprise and helps to determine the main guidelines for the development and implementation of innovative solutions. The author reflects on the most important properties of economic innovation processes, which enables us to significantly distinguish them from other business processes. Conclusions of research. It was concluded that in the conditions of the modern economic environment, innovation for an enterprise is a necessary condition for survival. However, by introducing innovations, managers of all levels are faced with the problem of uncertainty of new factors that have a significant impact on the progress of the innovation process and on the activity of the enterprise as a whole. The research results can be used in the development of strategies for the implementation of the innovation process in an enterprise of any form of organization.

Key words :

Stable development, Innovation, strategy of the organization, innovation process.

\section{ИННОВАЦИИ КАК СОСТАВЛЯЮЩАЯ ФАКТОРОВ ВЛИЯНИЯ НА СТАБИЛЬНОЕ РАЗВИТИЕ СОВРЕМЕННОГО ПРЕДПРИЯТИЯ}

Постановка проблемы. Ориентация на инновационное развитие и экономический рост, обеспечиваемый им, позволяют сегодня добиться предприятиям конкурентных преимуществ не только в производстве и реализации продукции (работ, услуг), но и прежде всего в способах организации бизнеса. Теория инновационного развития в экономике, которая является одной из главных экономических доктрин современности для большого числа стран мира, в Украине сейчас только формируется и находится в стадии активного развития. Рассмотрение особенностей и проблем инновационных процессов отечественных предприятий обусловлен необходимостью повышения их конкурентоспособности на внутренних и внешних рынках. Цель статьи заключается в развитии теоретико-методических основ в сфере развития предприятия на основе инноваций, а так же в определении роли инноваций для обеспечения стабильного развития предприятия. Объектом исследования выступает формирование инновационной стратегии предприятия и ее компонентов для реализации инновационного проекта. Meтоды, использованные в исследовании: системный подход, метод обобщения, сравнения. Основной гипотезой является то, что инновации играют важную роль в обеспечении стабильного развития предприятия. Изложение основного материала. Определено, что инновационное развитие является следствием инновационных процессов, происходящих на предприятии. В своем инновационном развитии предприятия проходят ряд стадий: научные исследования, освоения и внедрения. Основными свойствами инновации являются научная новизна, практическая применимость, коммерческая реализуемость. Рассмотрена методика формирования стратегии для внедрения инновации, ее виды для повышения конкурентоспособности предприятия, стадии и составляющие инновационного процесса. А также факторы, которые могут повлиять на формирование и результат инвестиционно-инновационного проекта. Оригинальность и практическое значение исследования. Статья дает представление о роли инноваций для современного предприятия и помогает определить основные ориентиры развития и внедрения инновационных решений. Автором отражены важнейшие свойства экономических инновационных процессов, которые существенно отличают их от других бизнес-процессов. Выводы исследования. Сделаны выводы, что в условиях современного экономического среды инновации для предприятия - необходимое условие выживания. Однако внедряя инновации руководители всех звеньев сталкиваются с проблемой неопределенности новых факторов, которые оказывают существенное влияние на «работу» инновационного процесса и на деятельность предприятия в целом. Результаты исследования могут быть использованы при разработке стратегии реализации инновационного процесса на предприятии любой формы организации.

\section{Ключевые слова:}

стабильное развитие, инновации, стратегия предприятия, инновационный процесс. 
Постановка проблеми. Тема стабільного розвитку підприємств отримала особливу актуальність після фінансово-економічної кризи, що вразила світову економіку в 2007 році, а протягом наступних років, призвела до значного погіршення основних показників, зниження довіри до стійкості ринкової економіки, платоспроможності підприємств і навіть до стабільності розвитку економічного сектору окремих держав світу, надійності економічних систем держав.

В умовах глобалізації міжнародних політичних і економічних відносин, прискорення інтеграції процесів світового розвитку, виникнення глобальних екологічних і соціальних викликів стратегічними цілями будьякого підприємства $є$ забезпечення стабільного розвитку і збереження положення на ринку.

Різні типи модернізації по-різному впливають на основні показники сталого розвитку підприємства, тому для підприємства необхідно виявити набір ключових факторів стабільного розвитку для цілей оцінки ступеня впливу на них різних типів модернізації. Певною гарантією стабільного розвитку і постійного вдосконалення діяльності організації $€$ впровадження інноваційних рішень та технологій. Сам інноваційний процес представляє собою здійснення комплексу заходів 3 підготовки виробництва, планування нових конкурентоспроможних товарів та послуг, що задовольнятимуть наявні та майбутні потреби споживачів, та сприятимуть досягненню балансу інтересів виробників, споживачів, партнерів, власників, персоналу організації, а також суспільства в цілому. Актуальність теми обумовлена тим, що розробка, виготовлення та реалізація інноваційної продукції, або надання послуг для забезпечення розвитку і стабільної позиції на ринку вимагає від підприємства та його керівництва визначення та аналізу економічних складових інноваційного процесу.

Аналіз останніх досліджень і публікацій. Загальнотеоретичні питання формування механізму стійкого розвитку підприємств та їх успішного функціонування в умовах ринкової економіки в різний час були розглянуті в працях: «Конкурентна перевага: як досягти високого результату і забезпечити його стійкість» М.Портера [1], «Стратегічний менеджмент» А.Томпсона [2], «Інноваційний менеджмент» Р.А.Фатхутдінова [3], «Конку- ренція: теорія і практика» А.Ю.Юданова [4], «Методологічні аспекти управління інноваційною діяльністю промислового підприємства» М.В.Чебикіної [5], «Організаційноекономічні основи підвищення конкурентоздатності легкої промисловості» I. М. Смолейчук [6], Т. І. Фрадіної та інших.

При розробці механізму стійкого розвитку істотне значення має оцінка рівня розвитку промислового підприємства та потенціалу його функціонування в конкурентному середовищі. Різні варіанти алгоритму такої оцінки пропонують у своїх роботах: «Стратегічне планування і управління на підприємствах будівельного комплексу» Р.К.Горшкова [7], «Менеджмент орієнтований на ринок» Ж. Ж. Ламберна [8], «Академія ринку: маркетинг» А. Дайана, Р. Урсе, А. Оллівье [9], «Комплексна оцінка конкурентоспроможності підприємства» В.А.Мошнова [10], «Виробничий менеджмент» М.В.Карманова [11] та інших.

Мета статті полягає у визначенні ролі інновацій та їх теоретико-методичних засад для забезпечення стабільного розвитку підприємства, визначення складових інноваційного процесу, які дозволяють у подальшому оптимізувати управління інноваційною діяльністю підприємств

Виклад основного матеріалу дослідження. В умовах ринкової економіки для підтримки рівня конкурентоспроможності, підприємство повинно не тільки випускати товар, який користується попитом, а й має привносити в свою виробничу діяльність щось нове, раніше незвідане, інноваційне. Не можна допускати, щоб вироблений товар 3 часом здавався застарілим, тому підприємству слід розробляти свої інноваційні ідеї. Саме тому успішність компанії більшою мірою мистецтво, яке спирається на досвід керівництва підприємства або організації, ніж інструмент впевненого якщо не розрахунку, то прогнозування. У ряді робіт Сідоріна А.В. була запропонована модель сталого розвитку підприємства [12-15]. В їі основі - траєкторія безперервного поліпшення діяльності без урахування багатьох зовнішніх, в тому числі і дестабілізуючих чинників, включаючи конкурентне середовище, зміна споживчої активності, стан зовнішньої і внутрішньої конфігурації підприємства, інноваційної діяльності підприємства та його конкурентів. 
У зв'язку з цим доцільно розглянути модель сталого розвитку підприємства на основі його інноваційної діяльності. У цій моделі і мета реінжинірингу, і об'єкт діяльності - інновації. Використовуючи інноваційний підхід до забезпечення свого сталого розвитку та позитивної динаміки зміни ефективності своєї діяльності, підприємство формує траєкторію своєї діяльності як чергування реінжинірингу, що складається в створенні і peaлізації інноваційного продукту, з постійним поліпшенням діяльності підприємства при стійкому, але вже не настільки інтенсивному отриманні прибутку i, відповідно, підвищення ефективності підприємства від реалізації інноваційного продукту 3 подальшим переходом до пошуку нового об'єкта інноваційної діяльності, його впровадження і реалізації для досягнення все більш нових показників результативності та ефективності, отримання прибутку [16]. I якщо з вибором інновацій як джерелом підвищення ефективності та потенціалу сталого розвитку підприємства проблема зводиться до пошуку, розробки та просування інноваційних продуктів, тобто до вирішення переважно інженерно-технічних питань - винаходів, науково-дослідних, дослідно-конструкторських робіт, виробничих завдань, то визначення своєчасності реінжинірингу, тобто впровадження інновацій, почати пошук перспективних напрямків розвитку і розробки нових технічних рішень швидше вміння керівництва підприємства, в основі якого, крім досвіду і аналітичного передбачення, такі інструменти як бенчмаркінг, менеджмент ризику, інноваційний та стратегічний менеджмент.

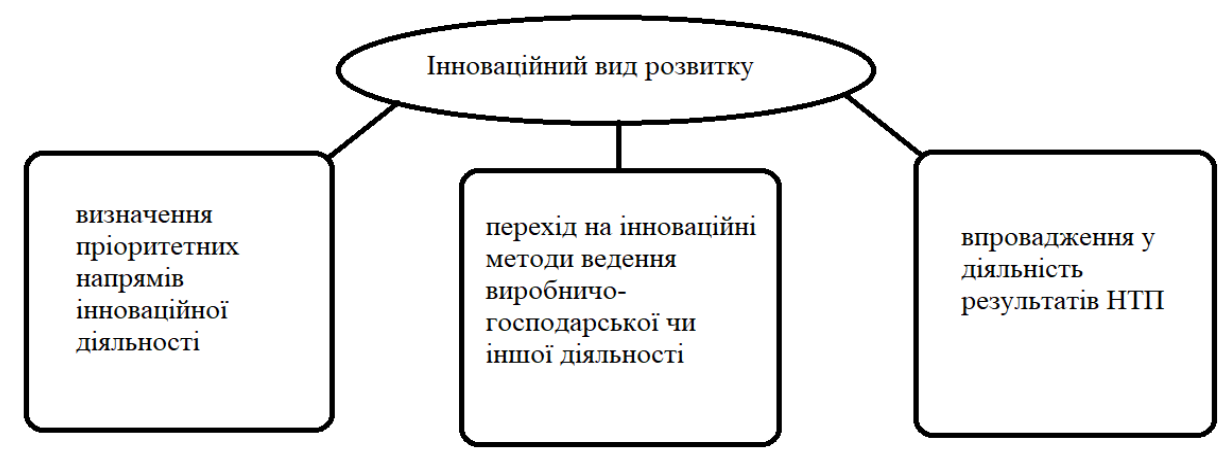

Рис. 1. Напрями економічного розвитку підприємства Джерело: розроблено автором на підставі [17]

Кожна інновація реалізується на основі інноваційного циклу, що включає кілька етапів, від задуму про створення інновації до ііі комерціалізації. Укрупнено інноваційний процес можна розділити на дві основні стадії: перша стадія (вона найдовша) включає в себе наукові дослідження та конструкторські розробки, друга стадія являє собою життєвий цикл продукту.

Таким чином, інноваційний процес починається з задуму (формування концепціі), усвідомлення потреби в наукових і технологічних нововведеннях, слушної нагоди їх здійснення на основі відкриттів і винаходів i комерціалізації винаходів і розробок у нові технічно досконалі види промислової продукції, засоби і предмети праці, технології і організацію виробництва і перетворення їх на джерело доходу. Життєвий цикл нововведення (рис. 2), інтегруючи цикли всіх інших бізнес-процесів, додаючи до них інноваційний етап, завжди залишається найбільш витратним за часом процесом, пов'язаним 3 максимальними проблемами отримання ефекту [18]. Інноваційний процес, як показує досвід, найбільш активно проходить на його початкових етапах. Багато уваги і часу в цей період приділяється саме генеруванню ідей, які в подальшому повинні стати готовим інноваційним продуктом, але у більшості інноваційних процесів закінчуються нічим. М.Дж.Епштейн, Р.Шелтон та Т.Давіла, вивчивши досвід провідних компаній світу, дійшли висновку, що в підприємницькій діяльності існують так звані «міфи», тобто неправдиві, однак загальноприйняті судження, які сповільнюють упровадження та розвиток інновацій на підприємствах. Мова йде про те, що [19]:

1. Інновація не потребує революції всередині компанії.

2. Інновація - це не алхімія з містичними перебудовами. 
3. Інновація не зводиться лише до творчості та створення «креативної культури».

4. Інновація не обмежується лише процесами і інструментами системи стадій і підходів.

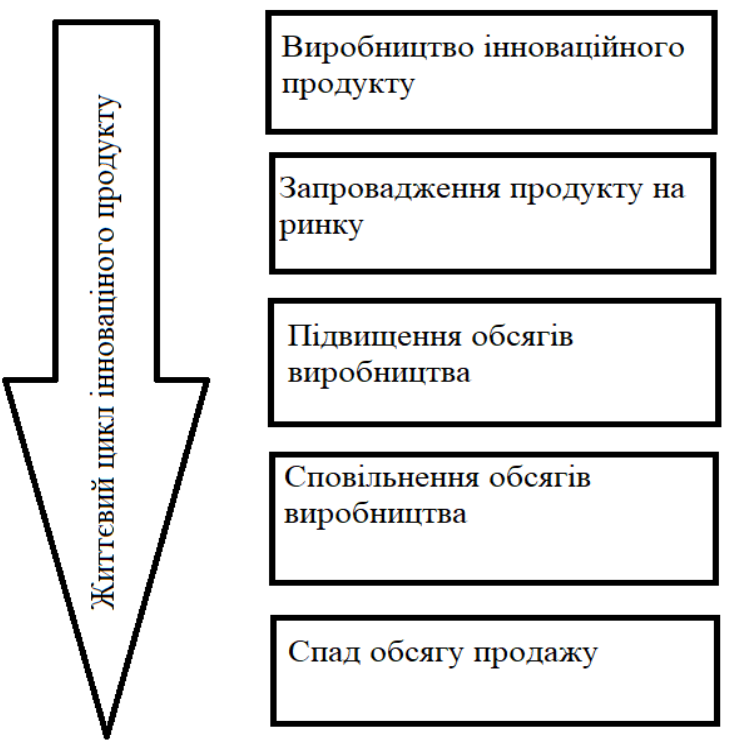

Рис. 2. Етапи інноваційного процесу у виробництві Джерело: розроблено автором на підставі [20]

У сучасних умовах інноваційні перетворення, насамперед, проявляються у кардинальній зміні елементів виробничих систем, створенні нових речовин і матеріалів [21]. Мова йде, зокрема, про заміну механічних і електромеханічних систем електронними системами, про використання міні- і мікроприладів, про створення нових видів матеріалів за допомогою нанотехнологій, про все більше застосування біотехнологій, комп'ютеризацію всіх виробничих і управлінських процесів. При цьому спостерігається масова ліквідація тих виробництв, що відповідали попередньому етапу індустріального розвитку суспільства.

Виникають кілька підходів до досягнення лідируючого положення: впроваджувати у виробництво нові інноваційні рішення або ж використовувати раніше придбані технології. До успішної або невдалої реалізації завдань інноваційної діяльності підприємства сприяє обрана стратегія інноваційного розвитку [22]. План стратегічного інноваційного розвитку організації повинен відповідати фінансовим і виробничим можливостям компанії. Кожна інновація супроводжується значним обсягом інвестицій і чим складніше вона технологічно, тим більші витрати потрібні
5. Інновація не зосереджується виключно на нових технологіях.

6. Інновація не $\epsilon$ тим, чого кожна компанія потребує найбільшою мірою.

для іiі створення і впровадження. Тому більш доцільно говорити про стратегію управління промисловим підприємством на інноваційній основі з урахуванням інвестиційної складової. На шляху накопичення фінансових ресурсів підприємство стикається 3 деякими перешкодами, по-перше, виробництво планованої інновації це ризикований процес, з непрогнозованими майбутніми доходами, особливо якщо фінансування проекту здійснюється за рахунок власних коштів. По-друге, якщо фінансування планується за рахунок позикових коштів, кредитори повинні бути переконані, що інноваційний проект має досить високий потенціал, в силу невизначеності терміну отримання очікуваного прибутку [23].

У якості різних видів стратегії з метою підвищення ефективності діяльності підприємства можуть бути обрані наступні підходи.

- Перехід на випуск нової продукції (послуг, виду діяльності) без зміни системи менеджменту підприємства.

- Розширення асортименту продукції, що випускається (послуг, видів діяльності) без зміни системи менеджменту підприємства. 
- Зміна системи менеджменту підприємства без зміни виду продукції, що випускається (послуг, виду діяльності).

- Розширення асортименту створюваної продукції, що випускається (послуг, видів діяльності) 3 одночасною зміною системи менеджменту підприємства.

- Зміна зовнішньої конфігурації підприємства без зміни виду продукції, що випускається (послуг, виду діяльності). Ці зміни можуть відноситися, зокрема, до системи взаємодії $з$ постачальниками, споживачами, ключовими партнерами та ін. Умовам взаємодії із зовнішнім середовищем підприємства).

- Зміна зовнішньої конфігурації підприємства 3 переходом на нові види продукції, що випускається (послуг, виду діяльності).

- Зміна внутрішньої і зовнішньої конфігурації підприємства 3 переходом на нові види продукції, що випускається (послуг, виду діяльності) [24].

Хоча інноваційні стратегії і орієнтуються на створення місії, але містять планування підцілей, які мають бути досягнуті у короткостроковий період. Обов'язковою вимогою є підпорядкованість підцілей головній меті підприємства. Структурованість інноваційної стратегії дає змогу застосувати альтернативу у певній частині стратегії без шкоди іншим складовим.

У сучасній економіці прийнято виділяти ряд факторів, які $є$ теоретикометодологічною основою побудови моделі інноваційного підприємства, цілком придатною до бізнесу. До їх числа відносяться:

- ресурсозабезпеченість. Це повнота та достатність забезпечення підприємства всіма необхідними ресурсами для організації та ведення інноваційної діяльності. До таких ресурсів можна віднести матеріальні, інформаційні, технологічні, трудові та інші види ресурсів;

- ефективність. До неї відносяться економічні показники функціонування підприємства, такі як рентабельність, ліквідність інвестицій, забезпеченість власними коштами, величина прибутку (виручки) від продажу або виробництва інноваційної продукції в загальній частці прибутку (виручки);

- збалансованість. Даний фактор полягає в застосуванні збалансованої системи оцінки показників фінансово-господарської діяльності підприємства;
- керованість. Суть даного чинника полягає в тому, щоб фактичні показники функціонування інноваційної системи в розумній мірі відповідали запланованим;

- синхронність. Даний елемент являє собою координацію всіх частин інноваційного процесу з метою їх гармонізації для досягнення найбільш стабільного розвитку інноваційного підприємства [25].

Зазначені вище фактори набувають особливого значення при організаційній формі ведення інноваційної діяльності, яка передбачає об'єднання інноваційних підприємств 3 метою реалізації масштабного капіталомісткого проекту в зв'язку з ускладненням структури і децентралізацією функцій економічних суб'єктів. Варто відзначити також, що в разі, коли підприємства об'єднуються для реалізації інноваційного проекту, необхідність створення даної служби в кожної компанії відпадає, оскільки ії̈ функція може бути передана спеціалізованому суб'єкту, що спеціалізується на професійному управлінні проектом, або виконанні маркетингових досліджень ринку відповідної продукції, технології, послуги. Це також значною мірою дозволяє скоротити витрати, пов'язані з запуском і подальшою реалізацією інноваційного проекту [26].

Саме тому правильно складений інноваційно-інвестиційний проект повинен містити відповідь на питання: чи варто інвестувати даний проект та чи принесе проект прибуток, за допомогою якого окупляться витрати? На практиці, інноваційно-інвестиційний проект являє собою документ, в якому подане техніко-економічне обгрунтування проекту, з урахуванням встановлених термінів виконання проекту, обсягу необхідних капітальних вкладень, включаючи проектно-кошторисні розрахунки, а також механізм дій щодо реалізації інвестицій. Важливо врахувати всі необхідні деталі проекту для прогнозування можливих майбутніх проблем, оцінки їх масштабу та для того, щоб заздалегідь спроектувати їх рішення [27]. Для цього використовується стратегічне планування. Воно характеризує методи управління організацією в довгостроковій перспективі та визначає комплекс необхідних ресурсів та подальші дії керівництва та організації в цілому для досягнення стратегічних цілей. Як відомо, гроші і час це обмежений ресурс, тому вкрай важливо оптимально розподілити ресурси серед потреб організації. Раціональне використання 
наявного ресурсного забезпечення становить основу стратегічного планування. Не можна керуватися принципом «хвилинності» і використовувати ресурси підприємства в міру ї необхідності, без системи розподілу ресурсів за ступенем важливості. На думку автора, через відсутність чіткої структури наявних ресурсів та розуміння характеру взаємовідносин між учасниками інноваційної діяльності в індустрії промислових підприємств спостерігається диспропорція між наявністю інноваційних можливостей i їх здійсненням на практиці [28].

Висновки та перспективи подальших досліджень. 3 вище сказаного виходить, що для стабільного розвитку компанії, особливо в сучасному нестабільному середовищі, швидких змінах, впровадження інновацій $є$ необхідною умовою виживання підприємства. Окрім того виявлено, що найбільше інноваційні процеси впливають на організації, які працюють в умовах невизначеності, а також на ті, які швидко розвиваються, впроваджуючи нові продукти чи послуги. А при відсутності єдиного підходу у вирішенні питань та завдань в області формування системи стратегічного управління виробничим процесом підприємства, а також внаслідок неналежного зіставлення його галузевих, регіональних i організаційних особливостей розвитку виникає диспропорція між інноваційними процесами та запровадженням їх на практиці. Тому перед керівниками всіх ланок постає проблема аналізу і найповнішого врахування різноманітних факторів впливу на впровадження інновацій на підприємстві та недопущення дисбалансу у структурі інноваційного процесу та інноваційної стратегії підприємства. Перспективи подальших досліджень полягають саме в аналізі та визначенні повного спектру факторів, які мають істотний вплив на стабільне становище підприємства.

\section{Література}

1. Портер М. Конкурентна перевага: як досягти високого результату і забезпечити його стійкість / М. Портер ; пер. 3 англ. - М. : Альпіна Бізнес Букс, 2005. - 715 с.

2. Томпсон A. A. Стратегический менеджмент : концепции и ситуации для анализа : пер. с англ.; 12-е изд. / А. А. Томпсон, А. Дж. Стрикленд. - М.: Вильямс, 2006. - 928 с.
3. Фатхутдинов Р. А. Инновационный менеджмент : учебник / Р. А. Фатхутдинов. - 4е изд. - СПб. : Питер, 2003. - 400 с.

4. Юданов А. Ю. Конкуренция: теория и практика: учеб.- практ. пособие. - М.: Изд-во ГНОМ и Д, 2001. $-304 \mathrm{c.}$

5. Чебыкина М. В. Методологические аспекты управления инновационной деятельностью промышленного предприятия. - St. Louis, Missouri, USA: Publishing House Science and Innovation Center, 2016. - $14 \mathrm{c}$.

6. Смолейчук И. М. Организационноэкономические основы повышения конкурентоспособности легкой промышленности: Дис. на получение степени док. экон. наук. - Владивосток, 2003. - $105 \mathrm{c}$.

7. Гориков Р. K. Стратегическое планирование и управление на предприятиях строительного комплекса / Р. К. Горшков, А. В. Ульянова. - Москва : Московский гос. строительный ун-т, 2013. - $182 \mathrm{c}$.

8. Ламбен Ж. Ж. Стратегический маркетинг: пер. с франц. / Ж. Ж. Ламбен. - СПб. : Наука, 1996. - 752 с.

9. Оллівье А. Международный маркетинг / А. Оллівье, А. Дайан, Р. Урсе // Академия рынка: Маркетинг / пер. с фр. А. Дайан, Ф. Бруккерель и др. - М.: Экономика, 1993. - 560 с.

10. Мошнов В. А. Комплексная оценка конкурентоспособности предприятия / В. А. Мошнов // Корпоративный менеджмент, 2014. [Електронний ресурс] - Режим доступу: http://www.cfin.ru/management/strategy/estimate_ competitiveness.shtml

11. Карманов М. В. Производственный менеджмент. Под редакцией Леонтьевой Л. С. и Кузнецова В.И. М.:ЮРАЙТ, 2015. - 305 с.

12. Сидорин В. В. Система менеджмента устойчивого развития предприятий обороннопромышленного комплекса / В. В. Сидорин // Методы менеджмента качества. - 2012. - №1. C. 14-17.

13. Сидорин А. В. Анализ и прогнозирование конкурентоспособности инновационной продукции / А. В. Сидорин // Интернетжурнал «Науковедение». - 2013. - №1 (14) [Електронний peсурс] - Режим доступу: http://naukovedenie.ru/sbornik6/4.pdf

14. Сидорин A. В. Анализ и прогнозирование устойчивого развития предприятия / А. В Сидорин : Материалы Международной научнотехнической конференции «Фундаментальные проблемы радиоэлектронного приборостроения», 3-6 декабря 2013, г. Москва. - М.: МИРЭА, 2013, часть 6. - С. 82-85.

15. Сидорин А. В. Оценка конкурентоспособности радиоэлектронных средств на этапе 
проектирования по комплексному вектору качества / А. В. Сидорин : Материалы научнопрактическую конференцию «Актуальные проблемы и перспективы развития радиотехнических и инфокоммуникационных систем» РАДИОИНФОКОМ-2013. - Москва-2013. - С. 22-27.

16. Сидорин A. В. Модель устойчивого развития предприятия на основе инновационной деятельности / А. В. Сидорин, В.В.Сидорин // Международный журнал прикладных и фундаментальных исследований. - 2014. - № 92. - C. 35-40.

17. Передрій $A$. E. Інноваційне управління підприємством в сучасних умовах / А. Е. Передрій // Вісник Національного технічного університету «Харківський політехнічний інститут» (економічні науки). Харків : НТУ «ХПИ», 2017. - № 24 (1246). - С. 40-43

18. Блюм $M . A$. Основы коммерческой деятельности: учебное пособие / М. А. Блюм, Н. В. Дюженкова, Н. В. Молоткова и др. - Тамбов : Изд-во ФГБОУ ВПО «ТГТУ», 2016. - 112 с.

19. Давила T. Работающая инновация: Как управлять ею, измерять её и извлекать из неё выгоду / Т. Давила, М. Эпштейн, Р. Шелтон; пер. с англ. Т.Ф. Козицкой. - Днепропетровск : Баланс Бизнес Букс, 2007. - 320 с.

20. Янковська О. І. Еволюція моделей інноваційного процесу / О. І. Янковська // Економіка. Управління. Інновації: електронне наукове фахове видання [Електронний ресурс] - Peжим доступу: https://wwwjibuv.gov.ua/ejoumals/eui/2009_2/09yoimip.pdf.

21. Микитюк П. П. Інноваційний менеджмент : навч. посіб. / П.П. Микитюк. - Тернопіль : Економічна думка, 2006. - 295 с

22. Федорова B. A. Теоретичні відомості 3 питання інновацій / В. А. Федорова, Ю. І. Татарчук // Економічний простір. - 2015. - № 100. C. 66-73.

23. Серёмина Р. Н. Инновационные процессы как объект инвестирования / Р. Н. Серемина // Молодой ученый. - 2016. - №19. - С. $513-515$.

24. Димитров И. Л. Планирование инноваций как организующее начало процесса реализации инновационного проекта / И. Л. Димитров // Молодой ученый. - 2012. - №12. - С. 197-198.

25. Чаадаева Н. В. Инновационная модель развития предприятия в современных условиях / Н. В. Чаадаева, В. В. Никитина [Електронний ресурс] - Режим доступу: http://sibac.info/index.php/2009-07-01-10-2116/4766-2012-11-20-13-00-07
26. Гелета И. В. Инновационная деятельность как важный фактор конкурентоспособности малых предприятий / И. В. Гелета, А. В. Щербак // Современные научные исследования и инновации. - 2015. - № 8. Ч. 1; [Електронний pecypc] - Режим доступу: http://web.snauka.ru/issues/2015/08/56720

27. Тяжкороб $I . \quad B$. Інноваційноінвестиційні проекти енергозбереження в системі стратегічних планів розвитку регіону / I. В. Тяжкороб // Фінансово-кредитна діяльність: проблеми теорії та практики. - 2015. - Вип. 2. C. 251-259.

28. Сафин Р. Ф. Процесс формирования стратегии инновационного развития производственного предприятия / Р. Ф. Сафин, О. Н. Соколова // Вестник Алтайского государственного аграрного университета. - 2011. - №1(75). - С. 109-116.

\section{References}

1. Porter, M. (2005). Competitive advantage: How to achieve high results and ensure its sustainability. Moscow: Alpina Business Books, 715 .

2. Thompson, A. A. (2006). Strategic management: concepts and situations for analysis. Moscow: Williams, 928.

3. Fatkhutdinov, R. A. (2003). Innovative management. Saint Petersburg: Piter, 400.

4. Yudanov, A. Yu. (2001). Competition: Theory and Practice. Moscow: Publishing house GNOM and D, 304.

5. Chebykina, M. V. (2016). Methodological aspects of innovation management of an industrial enterprise. St. Louisiana, Missouri, USA: Publishing House Science and Innovation Center, 14.

6. Smoleichuk, I. M. (2003). Organizational and economic foundations of improving the competitiveness of light industry. Dissertation of doctor of science degree. Vladivostok, 105.

7. Gorshkov, R. K. (2013). Strategic planning and management at the enterprises of the construction complex. Moscow: Moscow State Construction University, 182.

8. Lambin, J.-J.(1996). Strategic marketing. Saint Petersburg: Science, 752.

9. Allie, A. \& Dayan, A. \& Ursay, R. (1993). International Marketing. Moscow: Economy, 560.

10. Moshnov, V. A. (2014). Comprehensive Assessment of Enterprise Competitiveness. Retrieved from: http://www.cfin.ru/management/strategy/ estimate_competitiveness.shtml 
11. Karmanov, M. V. (2015). Production management. Moscow: YRAIGHT, 305.

12. Sidorin, V. V. (2012). System of management of sustainable development of enterprises of the defense industry complex. Methods of quality management, 2, 16-22

13. Sidorin, A. V. (2013). Analysis and forecasting of the competitiveness of innovative products. Internet magazine «Science», 1(14). Retrieved from: http://naukovedenie.ru/sbornik6/4.pdf

14. Sidorin, A. V. (2013). Analysis and forecasting of the sustainable development of the enterprise. Materials of the International Scientific and Technical Conference "Fundamental Problems of Electronic Electronic Instrumentation", 6, 82-85

15. Sidorin, A. V. (2013). The evaluation of the competitiveness of radio electronic equipment at the design stage for a comprehensive quality vector. Materials of the scientific and practical conference "Actual problems and prospects of the development of radio engineering and infocomm nication systems", 22-27.

16. Sidorin, A. V. \& Sidorin, V. V. (2014). The model of sustainable development of the enterprise on the basis of innovation activity. International Journal of Applied and Fundamental Research, 9-2, 35-40.

17. Priority, A. E. (2017). Innovative enterprise management in modern conditions. Bulletin of the National Technical University "Kharkiv Polytechnic Institute" (economic sciences), 24 (1246), 40-43.

18. Blum, M. A. (2016). Fundamentals of Commercial Activity: tutorial. Tambov: Publishing of FGBOOU VPO «TSTU», 112.

19. Davila, T. \& Epshtein, M. J. \& Shelton, $R$. (2007). Making innovation work: how to manage it, measure it, and get profit from it. Dnepropetrovsk: Balance Business Books, 320.

\footnotetext{
Стаття надійшла

до редакції : 01.03.2019 p.
}

20. Yankovskaya, O. I. (2009). Evolution of Models of Innovation Process/ In O. I. Yankovskaya, Economics. Management. Innovations: electronic scientific professional edition. Retrieved from: www.jibuv.gov.ua/ejoumals/eui/2009_2/09yoimip.pdf.

21. Nikitauk, P. P. (2006). Innovation Management: Teach. Manual, 295.

22. Fedorova, V.A. \& Tatarchuk, Yu. I. (2015). Theoretical information on innovation. Economic space, 100, 66-73. Retrieved from: http://nbuv.gov.ua/UJRN/ecpros_2015_100_9

23. Ser'minina, R. N. (2016). Innovative processes as an investment object. Young Scientist, 19, 513-515.

24. Dimitrov, I. L. (2012). Planning of innovations as organizing the beginning of the process of implementation of the innovation project. Young Scientist, 12, 197-198.

25. Chaadayeva, N. V. \& Nikitina, V. V. (2012). Innovative model of enterprise developm nt in modern conditions. Retrieved from: http://sibac.info/index.php/2009-07-01-10-2116/4766-2012-11-20-13-00-07

26. Geleta, I. V. \& Shcherbak, A. V. (2015). Innovative activity as an important factor of competitiveness of small enterprises. Modern scientific researches and innovations. 8, 1. Retrieved http://web.snauka.ru/issues/2015/08/56720

27. Tyazhkorob, I. V. (2015). Innovationinvestment projects of energy saving in the system of strategic plans of the region's development. Financial and credit activity: problems of theory and practice, 2, 251-259.

28. Safin, R. F. \& Sokolova, O. N. (2011). The process of forming a strategy for the innovative development of a production enterprise. Newspaper of the Altai State Agrarian University, 1 (75), 109-116.

\section{Стаття прийнята}

до друку: 29.03.2019 p.

\section{Бібліографічний опис для цитування :}

Луцишина Є. В. Інновації як складова факторів впливу на стабільний розвиток сучасного підприємства / Є. В. Луцишина // Часопис економічних реформ. - 2019. - № 1 (33). - С. 36-44. 